\section{A new species of the genus Zamarada Moore (Lepidoptera: Geometridae) from Shivaliks in Punjab, India}

\author{
Rachita Sood ${ }^{1}$, H.S. Rose ${ }^{2}$ \& P.C. Pathania ${ }^{3}$ \\ ${ }^{1}$ Department of Zoology, Guru Nanak (PG) Girls College, Model \\ Town, Ludhiana 141002, India \\ ${ }^{2}$ Department of Zoology, Punjabi University, Patiala 147002, India \\ ${ }^{3}$ Department of Entomology, Panjab Agricultural University, \\ Ludhiana 141004, India \\ Email: ${ }^{3}$ pathaniapc@yahoo.co.in (corresponding author)
}

\begin{abstract}
Abbreviations: $1 \mathrm{~A}$ - First anal vein; $2 \mathrm{~A}$ - Second anal vein; $3 \mathrm{~A}$ - Third anal vein; $1 A+2 A$ - Vein representing fused first and second anal vein; ASL - Above sea level; CuA1 - First cubital vein; CuA2 - Second cubital vein; CuP - Cubital posterior vein; M1 - First median vein; M2 Second median vein; R1 - First radial vein; R2 - Second radial vein; R3 - Third radial vein; R4 - Fourth radial vein;R5 - Fifth radial vein; Rs Radial sector; Sc - Subcostal vein; Sc+R1 - Stalk of subcostal and first radial vein.
\end{abstract}

Hampson (1895) redescribed the genus Zamarada Moore, with Z. translucida Moore as its type-species. Fletcher (1979) considered the latter species as a junior subjective synonym of Euchloris baliata Felder \& Rogenhofer. Recently, Holloway (1993) revised the genus, and considered Z. translucida Moore and Euchloris baliata as synonyms of Z. baliata Felder \& Rogenhofer. Six species i.e., baliata, scriptifasciata, denticulata, nesiotica, ucatoides and eogenaria have been included under Zamarada by Holloway. Out of these species, the latter has been reported from India. All these species have been distinguished on the basis of the female genitalia. The genitalia of the species described here were compared with the illustrations of these described species, and since the collected sample does not conform to any of them the unnamed species is reported as Zamarada pseudobaliata sp. nov. The types are deposited in the Lepidoptera Laboratory, Department of

Date of online publication 26 April 2009

ISSN $0974-7907$ (online) | 0974-7893 (print)

Editor: R.K. Varshney

Manuscript details:

Ms \# 01584

Received 28 June 2006

Final received 21 April 2008

Finally accepted 16 March 2009

Citation: Sood, R., H.S. Rose \& P.C. Pathania (2009). A new species of the genus Zamarada Moore (Lepidoptera: Geometridae) from Shivaliks in Punjab, India. Journal of Threatened Taxa 1(4): 236-237.

Copyright: (C) Rachita Sood, H.S. Rose \& P.C. Pathania 2009. Creative Commons Attribution 3.0 Unported License. JoTT allows unrestricted use of this article in any medium for non-profit purposes, reproduction and distribution by providing adequate credit to the authors and the source of publication.

Acknowledgements: We are grateful to the Punjab State Council of Science and Technology, Chandigarh for funding the project on moths and to the ViceChancellor, Punjabi University, Patiala for providing necessary research facilities. We thank Dr. V.V. Ramamurthy (Principal Scientist) for his help in consultation of the National Pusa collection housed at the Indian Agricultural Research Institute, New Delhi.

OPEN ACCESS | FREE DOWNLOAD
Zoology, Punjabi University, Patiala, Punjab, India.

\section{Zamarada pseudobaliata sp. nov.} (Figs. 1-5)

\section{Material examined}

Holotype: Male, 21.x.1999, Roopnagar, Roopnagar District, Punjab, 350m, coll. H.S. Rose \& Rachita Sood (LL/DZ/PUPGEO 01)

Paratypes: 9 males, 1 female, 23.x.2001, Dunera, Gurdaspur District, Punjab, 700m; 10 males, 8 females, 27.x.2001; 2 males, 23.viii.2002, Hoshiarpur, Hoshiarpur district, Punjab, 370m; 9 males, 23.x.2001, Dhar, Hoshiarpur district, Punjab, 650m, coll. H.S. Rose \& Rachita Sood (LL/DZ/PUP- GEO 02-40).

\section{Distribution}

India: Punjab: Roopnagar, Dunera, Hoshiarpur, Dhar.

\section{Etymology}

The species name is proposed after the name of the closely allied species, baliata.

\section{Male and Female}

Alar expanse: Male $30 \mathrm{~mm}$; Female $32 \mathrm{~mm}$. Antennae bipectinate to two-third length in both sexes, branches longer in male than female; hind tibiae not dilated; wings hyaline yellowish-green, with a few dark striae, a small sub-basal patch, a broad marginal band purplish grey irrorated with fuscous, deeply indented between veins $\mathrm{CuA} 2$ and $\mathrm{M} 3$, a dark speck at the end of cell; forewing with veins $\mathrm{R} 3$ to $\mathrm{R} 5, \mathrm{M} 2$ from middle of cell; hindwing with veins Rs and M1 connate, arising from upper angle of cell, M2 and M3 connate.

Wing venation (Figs. 1 \& 2): Forewing with Sc ending at 2/ 3rd of costa, $\mathrm{R} 2+\mathrm{R} 3+\mathrm{R} 4$ stalked, arising from upper angle of discal cell, R5 arising near the upper angle of discal cell, M1 absent, M2 arising from middle of cell, M3 and CuA1 arising from lower angle of discal cell, $\mathrm{CuA} 2$ from $2 / 3 \mathrm{rd}$ of cell, discal cell closed, $\mathrm{CuP}$ vestigial, visible at margin, $1 \mathrm{~A}+2 \mathrm{~A}$ forked at base; hindwing with $\mathrm{Sc}+\mathrm{R} 1$ ending near apex, Rs and M1 arcing at the upper angle of discal cell, M2 and M3 from lower discal angle of cell, $\mathrm{CuA} 1$ not traceable, $\mathrm{CuA} 2$ arising near middle of discal cell, $\mathrm{CuP}$ absent, $1 \mathrm{~A}+2 \mathrm{~A}$ present, $3 \mathrm{~A}$ absent.

Male genitalia (Figs. 3 \& 4): Uncus broad at base, narrower towards apex as if forming a dome-like structure, beset with setae, the latter densely arranged; gnathos arms fused in the middle, heavily sclerotised, impregnated with small hooks-like markings on the fused portion; tegumen long, sclerotised, Vshaped, arms narrow towards the base of uncus; vinculum broadly U-shaped; coremata present; valvae narrower, costal region given off into flange like processes called ampulla, the latter adorned with setae on the apical end, apex pointed, sacculus region well developed furnished with long setae, sacculus well sclerotised, sharp from apical end; transtilla thin; aedeagus passes terminally, slender, thick pointing towards vesica armed with cornuti, cornuti well developed, spine-like.

Female genitalia (Fig. 5): Ovipositor lobes long, adorned with setae; posterior apophyses of double length than anterior apophyses; ostium bursae rounded; sterigma ornamented with dorsal lobe, divided into three spines, the lateral digitate processes, apically serrate, central of same length as that of 

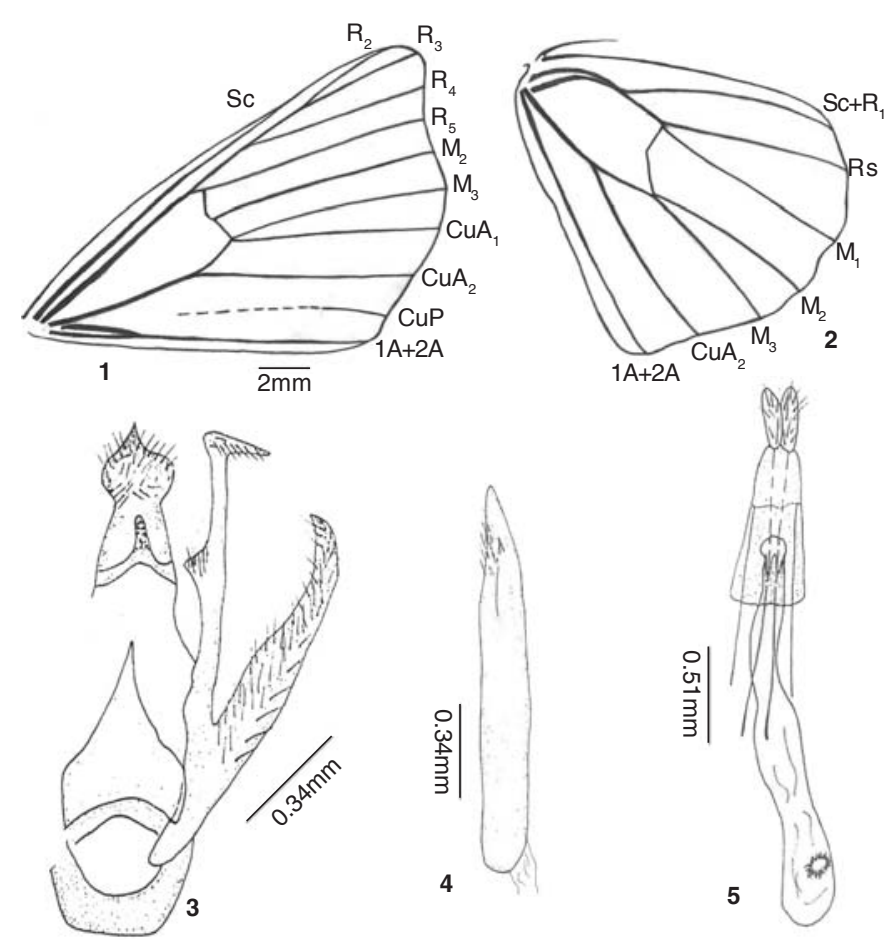

Figures 1-5. Zamarada pseudobaliata sp. nov.

1 - Forewing venation; 2 - Hindwing venation; 3 - Male genitalia ventral view; 4 - Aedeagus; 5 - Female genitalia ventral view

lateral spines but rounded anteriorly; ductus bursae striated internally; corpus bursae elongated, signum well defined; oval with uniformly arranged spines on the outer side.

Food plant: Not known.

\section{Discussion}

The critical examination of the genitalia reveals that though the species under reference is closely allied to baliata Felder \& Rogenhofer, yet differs in the shape of the sterigma in the female genitalia, as in case of baliata Felder the sterigma is ornamented with a dorsal lobe in all three spines and lateral digitate processes that are apically serrate in the first two. But in case of pseudobaliata sp. nov., the lateral digitate process are apically serrate in all the three and the central spine is of same length but rounded anterior, which is not the case in baliata Felder. Besides this, the male genitalia of baliata have an excavate area to the sacculus region of the valva and the costal region is not given off to a flange like process, which is adorned with setae in pseudobaliata sp. nov., and saccular region is also not so excavate and is sharp apically.

\section{References}

Fletcher, D.S. (1979). The Generic Names of Moths of the World. Volume 3. Geometridae. Trustees of the British Museum (Natural History), London, 243pp.

Hampson, G.F. (1895). Fauna of British India including Ceylon and Burma, Moths, 3: Taylor and Francis Ltd., London, 546pp.

Holloway, J.D. (1993). Moths of Boreno Part II Geometridae, Ennominae. Malayan Nature Journal 47: 1-309.

Klots, A.B. (1970). Taxonomists' Glossary of Genitalia in Insects. Munksgasard, Copenhagen Lepidoptera. pp.115-139 in Tuxen.

Landry, J.F. (1991). Systematics of Nearctic Scythrididae (Lepidoptera: Gelechioidea): Phylogeny and classification of supraspecific taxa, with review of described species. Memories entomological Society Canada 160: $1-341$.

Robinson, G.S. (1976). The preparation of slides of Lepidoptera genitalia with special reference to microlepidoptera. Entomological Gazette 27(2): 127-132

Zimmerman, E.C. (1978). Microlepidoptera. Insects of Hawaii, Vol. 9. University Press of Hawaii, Honololu, xviii+1903pp. 